\title{
LUKAS 10:1-16 AS BEGRONDING VAN DIE KERK SE SENDING IN LUKAS-HANDELINGE
}

Author:

Marius J. Nel ${ }^{1}$

\section{Affiliation:}

${ }^{1}$ Departement Nuwe

Testament, Universiteit van

Pretoria, Suid-Afrika

Correspondence to:

Marius Nel

email:

marius-nel@lantic.net

Postal address:

Posbus 80862, Doornpoort

0017, Suid-Afrika

\section{Keywords:}

Lukas; Missio Dei;

huiskerke; dissipelskap;

sending

\section{Dates:}

Received: 26 Jan. 2009

Accepted: 11 Dec. 2009

Published: 27 Aug. 2010

How to cite this article: Nel, M.J., 2010, 'Lukas 10:1-16 as begronding van die kerk se sending in Lukas-Handelinge', Verbum et Ecclesia 31(1), Art. \#372, 7 pages. DOI: 10.1402 ve.v31i1.372

\section{This article is available} at: http://www.ve.org.za

Note:

Dr Marius Nel is ' $n$ navorsingsgenoot by die Departement Nuwe Testament, Fakulteit Teologie aan die Universiteit van Pretoria.

(C) 2010. The Authors. Licensee: OpenJournals Publishing. This work is licensed under the Creative Commons Attribution License.

\section{ABSTRACT}

The mission of the church according to Luke 10:1-16

The sending out of seventy-two disciples by Jesus in Luke 10:1-16 provides both a theological justification and a modus operandi for the church's participation in God's mission to the world as described in Luke-Acts. Participating in the Missio Dei, the church must be willing to cross all economic and ethnic boundaries. Luke emphasises that the mission of the church is the result both of God's initiative and the influence of Jesus' continuing presence through his church. The primary focus of the church's mission is to establish a new household-based community in which all are welcome. For those who reject the message of peace of the seventy-two, however, the eschatological ramifications will be dire.

\section{INLEIDING}

Die artikel fokus op Jesus se sending van twee en sewentig arbeiders in Lukas 10:1-16 as 'n sleutelteks vir die begronding van die kerk se deelname aan die Missio Dei in Lukas-Handelinge. Daar word op dié spesifieke perikoop gefokus omdat dit in die verlede 'n afgeskeepte missionêre teks was, ${ }^{1}$ maar sedert 2003 'n sleutelteks vir die missionêre verstaan van gemeentes in die Suider-Afrikaanse Vennootskap vir Gestuurde Gemeentes (SAVGG) geword het. ${ }^{2}$ Binne die SAVGG word Lukas 10:1-12 egter meestal met 'n teksimmanente benadering gelees wat telkens die polivalensie van die teks se betekenis ontsluit. Aangesien tekste wel polivalent is, maar nie omnivalent nie, sal hierdie artikel Lukas 10:1-16 binne die literêre en historiese konteks daarvan lees ten einde tot 'n meer genuanseerde verstaan daarvan as 'n missionêre teks in Lukas-Handelinge te kom.

Ná enkele opmerkings oor die historisiteit, literêre konteks en opbou van Lukas 10:1-16, sal die identiteit van die twee en sewentig en die oes wat hulle moes insamel, aandag geniet. Die volgende sal ook aan die orde kom: die uitgestuurdes se taak, die belangrikheid van gebed en hulle instruksies oor hoe om op sowel positiewe as negatiewe ontvangste te reageer. Ten slotte sal kortliks gevra word na die wyse waarop Jesus in Lukas, en die kerk in Handelinge, aangesluit het by die twee en sewentig se sending. Lukas-Handelinge sal in die artikel as 'n literêre eenheid hanteer word as gevolg van die duidelike strukturele, stilistiese en tematiese ooreenkomste én ontwikkelings tussen die twee geskifte (Achtemeier, Green \& Thompson 2001:149, 154-156; Bock 2004:349; Bosch 1991:104; Johnson 1999:213-216, 222; Litwak 2005:35-47).

\section{Die historisiteit en redaksiegeskiedenis van die sending van die twee en sewentig}

Daar heers onsekerheid oor die historisiteit en die redaksiegeskiedenis van die sending van die twee en sewentig deur Jesus in Lukas 10. Die rede hiervoor is dat, hoewel daar parallelle vir vers 2 tot 16 in die Evangelies van Matteus en Tomas is, ${ }^{3}$ daar geen parallel vir vers 1 is nie. Die vertelling kan daarom óf 'n suiwer literêre skepping van Lukas wees (Crossan 1992:334; Fitzmyer 1985:842-843; Matson 1996:29-31; Robinson, Hoffmann \& Kloppenborg 2000:158), óf teruggevoer word tot sy eie bronne se weergawe van 'n historiese gebeurtenis (Bock 1996:986-988; Evans 1990:443-444; Nolland 1993:547548). Sonder toegang tot al Lukas se bronne is dit egter onmoontlik om die redaksiegeskiedenis en die historisiteit van die sending van die twee en sewentig met volkome sekerheid vas te stel (contra Robinson et al. 2000:158).

Ten opsigte van die historisiteit van Lukas-Handelinge in die algemeen is dit belangrik om kennis te neem van die groeiende konsensus onder Nuwe-Testamentici dat Lukas-Handelinge 'n voorbeeld van sosiologiese legitimasie is. Dit het naamlik ten doel om aan te toon hoe die nuwe inklusiewe gemeenskap van die kerk vanuit die Judaïsme ontstaan het. Lukas-Handelinge gee dus 'n bepaalde teologiese interpretasie van die kerk se ontstaansgeskiedenis (Bock 2004:350-351).

\section{Die literêre konteks van Lukas 10:1-16}

Lukas plaas die sending van die twee en sewentig aan die begin van Jesus se finale reis na Jerusalem (9:51-19:48). Dié reis word gekenmerk deur Jesus se onderrig van sy dissipels, en sy uitnodiging aan diegene langs die weg om hulle lewens volgens God se wil in te rig. In die reisverhaal vorm 10:1-16 'n afgebakende perikoop. Dit word van die voorafgaande perikoop afgegrens deur Lukas

1.Lukas 10:1-16 word byvoorbeeld nie deur Bosch (1991) of Wright (2006) hanteer in hulle omvangryke werke oor die Missio Dei nie.

2.Die belangrikheid van Lukas 10:1-12 in die SAVGG is te danke aan die werk van prof. Pat Keifert en Church Innovations (2006:68-71). Sedert 2003 het meer as ' $n$ tiende van alle gemeentes van die NG Kerk by die SAVGG aangesluit. Die SAVGG is ' $n$ veeljarige proses waardeur gemeentes begelei word om hulle spesifieke missionêre roepings binne hulle onmiddellike kontekste te onderskei.

3.Parallelle is Luk 10:2/Matt 9:37-38, Tomas 73; Luk 10:3/Matt 10:16; Luk 10:4-12/Matt 10:9-15; Luk 10:5-6/Matt 10:12-13; Luk 10:7/Matt 10:10, Tomas 14b; Luk 10:10-12/Matt 10:14-15; Luk 10:12/Matt 11:24: Luk 10:13-15/Matt 11:21-23 en Luk 10:15/Matt 11:23 


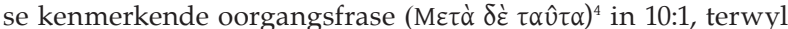
daar vanaf vers 17 verwys word na die terugkeer van die twee en sewentig ná hulle sending.

Lukas 10:13-16 sou as 'n afsonderlike perikoop beskou kon word. Aangesien die oordeelsaankondiging oor die Joodse stede in 10:13-15 egter aan 10:12 gekoppel word en 10:16 as 'n samevatting van die perikoop dien, word dit as deel van 10:1-16 geneem.

\section{DIE OPBOU VAN LUKAS 10:1-16}

A. Inleiding: Die sending van die twee en sewentig (10:1-4) Die aanwys en sending van die twee en sewentig (10:1) Oproep om te bid vir nog werkers om die oes in te samel (10:2) Waarskuwing oor die gevaar van die sending (10:3) Gedragskodes vir die sending (10:4)

B. Voorskrifte vir hoe om op verskillende ontvangste te reageer (10:5-11)

Indien positief of negatief ontvang in huise (10:5-7)

Indien positief ontvang in stede (10:8-9)

Indien negatief ontvang in stede (10:10-11)

C. God se oordeel oor die stede ${ }^{5}$ wat sy vrede verwerp (10:12)

D. Die lot van die stede wat Jesus se bediening verwerp het (10:13-15)

E. Samevatting: Die implikasie daarvan om die boodskap van die dissipels te glo of te verwerp (10:16)

\section{LUKAS 10:1-16 AS BEGRONDING VAN DIE KERK SE SENDING NA DIE WÊRELD}

\section{Die sending van die twee en sewentig dissipels} (10:1-4)

\section{Die sending van die twee en sewentig as deelname aan die Missio Dei}

Lukas beklemtoon in 10:1-2 dat die oes wat ingesamel moet word, aan God behoort. Hy wys ook daarop dat dit Jesus is wat die inisiatief neem vir die insameling daarvan deur arbeiders uit te stuur.

Die bediening van Jesus en sy gestuurdes is volgens Lukas die voortsetting van die één sending van God (die sogenaamde Missio Dei $)^{6}$ na die wêreld toe waarvan die Ou Testament vertel het (vgl. Litwak 2005:206; Schürmann 1994:59). Só bevestig die talle intertekstuele eggo's van die handelinge van God in die Ou Testament $(10: 4,6)$ dat dieselfde Here wat deur Moses, Elia en Elisa by sy volk teenwoordig was, in die sending van Jesus en die twee en sewentig werksaam was. Die gedagte dat die 'vrede

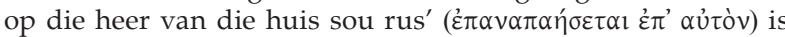
byvoorbeeld ' $n$ intertekstuele eggo van dieselfde idioom in die LXX. In 2 Konings 2:15 rus die gees van Elia naamlik op Elisa. 'n Soortgelyke gedagte kom voor in Numeri 11:25-26 waar die

Kyk Lukas 5:27; 12:4; 17:8; 18:4 en Handelinge 7:7; 13:20; $15: 16$ en 18:1 (Fitzmye 1985:845).

5.Lukas gebruik тó $\lambda_{1 \varsigma}$ met die betekenis van 'n bevolkingsentrum in kontras met ' landelike streek, sonder om die grootheid daarvan te spesifiseer (vgl. Louw \& Nida 1988:17-18). Só noem hy plekke 'stede' wat die ander evangelieskrywers 'dorpe' noem. In Joh 7:42 word Bethlehem byvoorbeeld 'n kẃun genoem, terwyl Lukas 2:4

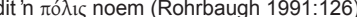

6.Die gebruik van die frase Missio Dei as begronding vir die sending van die kerk kan teruggevoer word na die Duitse missioloog Karl Hartenstein se samevatting van ' esing van Karel Bath in 1928. In dié lesing Ket Bath die sending van die k lie lor

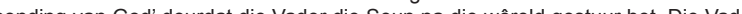
sen Gees die kerk uitgestuur. Volgens Barth is die Drie-enige God dus in wese 'n missionêre God. gees van Moses gerus het op die sewentig wat hy aangewys het om hom te help. Die gevolg daarvan was dat hulle tydelik in sy profetiese bediening gedeel het (Evans 1990:448). Soos Elisa in Elia se bediening gedeel het, en die sewentig in Moses $\mathrm{s}^{\prime} \mathrm{n}$, het diegene op wie God se vrede sou rus ook in die Missio Dei van die twee en sewentig gedeel (Nolland 1993:552, 559). Volgens Litwak (2005:2-4, 32-33, 56-57) lei dié verskillende Ou-Testamentiese intertekstuele eggo's in Lukas-Handelinge die leser om die gebeure in Lukas se narratief te verstaan deurdat dit die kontinuïteit tussen die kerk en Israel uitwys. Dit dui daarop dat, hoewel die gebeure in Lukas-Handelinge nie noodwendig altyd 'n direkte vervulling van bepaalde $\mathrm{Ou}$-Testamentiese profesieë is nie, dit wel ongetwyfeld die voortsetting van God se heilswerk is (Litwak 2005:12, 22).

Met die bediening van Jesus het die Missio Dei 'n nuwe, belangrike fase betree. In Lukas 24:44-48 open Jesus naamlik die dissipels se verstand om te verstaan dat alles wat in die $\mathrm{Ou}$ Testament geskryf is (24:44c) vervulling gevind het in sy dood en opstanding sowel as in die verkondiging daarvan aan al die nasies (24:47-48). Net só het Hy aan die Emmausgangers in 24:25-27 bekend gemaak dat die Ou-Testamentiese geskrifte reeds oor Hom getuig het (Goheen 2005:230-231; Wright 2004:107)

Lukas toon verder aan dat die Missio Dei ná Jesus se dood en opstanding voortduur. Die kerk se sending in Handelinge is vir hom die direkte voortsetting en uitbreiding van dié Missio Dei (Wright 2004:133-134), en nie die kerk se oorname van dié sending by God nie. Die Here bly immers steeds self aktief in die kerk se sending. Elkeen van die bekerings van 'n huishouding in Handelinge (kyk 5:2) word daarom voorafgegaan deur 'n direkte ingrype deur God self. Só ontvang Petrus, asook Paulus en Silas, visioene van God vóór hulle ontmoetings met Cornelius en Lydia onderskeidelik (Hand 10:3, 11; 16:9). Die bekering van die Romeinse tronkbewaarder volg op 'n wonderbaarlike aardbewing (Hand 16:26) en die bekering van Krispus (Hand 18:9-10) op 'n visie van God waarin Paulus beveel is om sonder vrees in sy huis aan te bly en die Evangelie aan hulle te verkondig (Matson 1996:196-197).

\section{Die identiteit van die twee en sewentig}

Diegene wat deur Jesus uitgestuur word, word in 10:1 net as

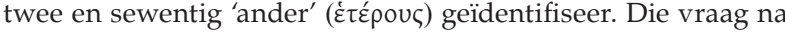
die identiteit van die twee en sewentig kan daarom gevra word. Was hulle bloot boodskappers of was hulle dissipels en selfs apostels van Jesus?

Die intra-tekstuur van 10:1-16 dui daarop dat die twee en sewentig as dissipels van Jesus gesien moet word (contra Völkel 1990:369). Die rede hiervoor is dat die kontras in 10:1

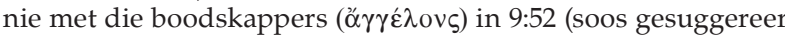

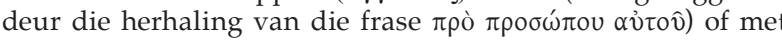
die potensiële dissipels in 9:57-62 is nie. Dit is eerder met die twaalf dissipels in 9:1-5 wat met byna identiese opdragte deur Jesus uitgestuur is (Marshall 1978:415; Nolland 1993:550). Lukas 22:35-38 bevestig dat die twee en sewentig en die twaalf dissipels volgens Lukas met dieselfde sending besig was. Jesus verwys naamlik na die twee uitsendings $(9: 1-5$ en $10: 1-11)$ asof hulle een sending was (Bock 1996:994; Nolland 1993:550). Alhoewel Jesus in 22:35-38 direk met die oorspronklike twaalf dissipels praat, verwys Hy in 22:35 ook na sy opdrag oor die saamneem van sandale wat Hy net aan die twee en sewentig gegee het (10:4)

Die doelbewuste parallelisme wat Lukas tussen die uitsending van die twaalf en die twee en sewentig daarstel, stel hom in staat om aan te dui dat die missionêre taak van die twaalf nie net tot hulle beperk was nie (Marshall 1978:413; Stein 1992:303-

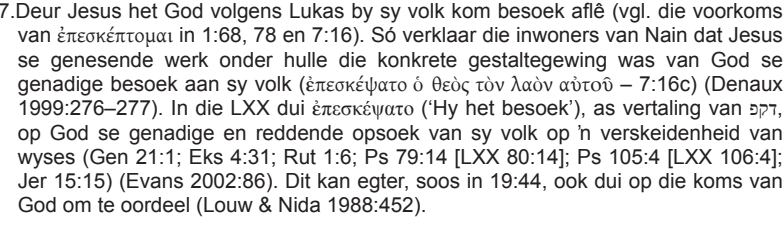

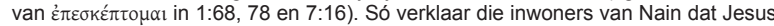
ve genesende werk onder hulle die konkrete gestaltegewing was van genesende werk onder hulle die konkrete gestaltegewing was van God se

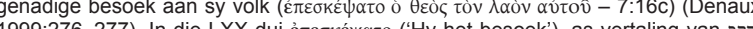
דקפ o God se genadige en reddende opsok van sy volk op h verskeidenheid van wyses (Gen 21.1, Eks 4.31, Rut 1.6; Ps 79:14 [LXX 80.14], Ps 105:4 [LXX 106:4] Jer 15:15) (Evans 2002:86). Dit kan egter, soos in 19:44, ook dui op die koms van God om te oordeel (Louw \& Nida 1988:452). 
304). Daar was ook ander dissipels of volgelinge van Jesus wat deur Hom uitgestuur is. Hulle getalle sou dan ook konstant toeneem. Só wys Lukas daarop dat die een gestuurde (Johannes die Doper), wat die weg vir Jesus moes voorberei (1:17, 76; 3:4; 7:27), se sending eers tot die twaalf dissipels uitgebrei is (9:1-6). Daarna is die twee en sewentig ander dissipels uitgestuur (10:1), met die vooruitsig dat hulle getalle ook nóg verder uitgebrei sou word (10:2). Laasgenoemde gebeur dan ook uiteindelik in Handelinge (Tannehill 1986:232, 236).

\section{Die taak van die twee en sewentig dissipels}

Die dissipels word deur Jesus in 10:2-3 uitgestuur met die opdrag om God se oes te gaan insamel. Alhoewel dié landboubeeld meestal in die $\mathrm{Ou}$ Testament van God se oordeel getuig het (Miga 4:11-13; Joël 3:13), dui dit hier eerder op die genadige innooi van alle mense in God se koninkryk (Jes 27:12) (Marshall 1978:416; Moessner 1989:135; Nolland 1993:558). Waar die twaalf dissipels siekes moes genees en die koms van die koninkryk verkondig (9:1-2), en die boodskappers in 9:51-52 die weg vir Jesus moes voorberei, moes die twee en sewentig dissipels beide groepe se take verrig (Green 1997:412; Johnson 1991:167). Hulle opdrag om stede vir die koms van Jesus voor te berei, het dus verder gestrek as net om slaapplek vir Hom te reël (Marshall 1978:416; Nolland 1993:550; Tannehill 1986:234). Om dié rede moes die dissipels nie net twee-twee reis ter wille van wedersydse ondersteuning nie, maar ook om te verseker dat hulle getuienis geloofwaardigheid sou hê (vgl. Num 35:30; Deut 19:15).

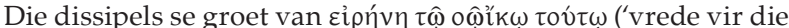
huis') dien in Lukas as 'n metonimie vir die allesinsluitende verlossing wat deur Jesus aangebreek het (vgl. 1:79; 2:14, 29; 7:50; 8:48; 19:38, 42; 24:36) (Green 1997:413; Matson 1996:45; Tannehill 1986:237). Dié verlossing is omvattend deurdat die GrieksRomeinse begrip van vrede (as die afwesigheid van oorlog en die teenwoordigheid van sosiale harmonie) in Lukas aangevul word deur die Ou-Testamentiese verstaan van shalom. Shalom is die besondere gemeenskaplike welstand, oorvloed en sekuriteit wat God alleen kan skenk (Fitzmyer 1985:848). God se vrede sou danksy die sending van die twee en sewentig rus op almal

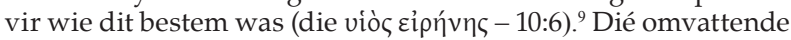
vrede sou ook konkrete gestalte vind in die genesing van almal wat siek was in die huise wat die dissipels ontvang het (kyk onder die hofie 'Die genesing van siekes en die verkondiging van die koninkryk van God').

Die verkondiging van die koms van die koninkryk van God

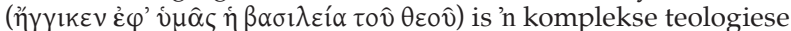
motief in die Lukas-evangelie (Bock 2004:357). Enersyds is God se koninkryk naby (10:9), en selfs reeds tussen mense

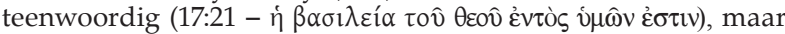
andersyds is die finale aanbreek daarvan vir Lukas nog in die toekoms (17:22-37). Terwyl die koms van die koninkryk reeds 'n teenswoordige effek het, met die gevolg dat die werk van die dissipels aanvaar of geweier mag word, sal die finale oordeel oor die verskillende stede (10:12) egter eers met die voleinding geskied (Green 1997:415-416; Nolland 1993:554).

\section{Die belangrikheid van gebed}

Lukas stel dit duidelik dat die twee en sewentig dissipels te min was vir die taak en dat hulle daarom die Here ${ }^{10}$ moes smeek om

8.Die aanduiding dat die twee en sewentig deur Jesus uitgestuur is, sou kon lei to 'n tipering van hulle as 'apostels', eerder as 'dissipels', aangesien die selfstandige naamwoord $\mu \alpha \theta \eta \tau$ ń nie in die gedeelte voorkom nie, maar die werkwoord

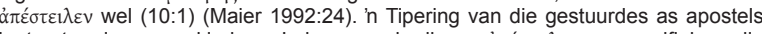

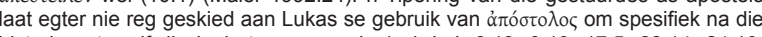
historiese twaalf dissipels te verwys nie (vgl. Luk 6:13; 9:10; 17:5; 22:14; 24:10; Hand 4:35-37; 5:2, 27-32; 6:6; 8:1, 14, 18; 9:27; 11:1; 15:1-6, 22-23; 16:4). Die enigste uitsondering hierop is Lukas se verwysing na Paulus en Barnabas as apostels in Handelinge 14:4 en 14 (Betz 1996:310).

9.Die uitdrukking 'seun van vrede' is uniek tot Jesus (Klassen 1996:208). Dit is in ooreenstemming met die Joodse gebruik om mense in terme van hulle gedrag te tipeer (bv 'seuns van die lig'-16:8) (Dunn 2003:710). Die vios eiphnc kan ve word ( $\mathrm{s}$ ' ' ' 'vredevolle persoon' of ' $\mathrm{h}$ 'persoon vir wi viod 1978:420).

10.Alhoewel Jesus in Lukas $(5: 12 ; 8: 28,38$ en 9:38) dikwels deur dieselfde werkwoord

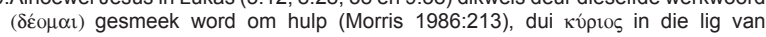

nóg werkers uit te stuur (10:2). Naas hulle opdrag om die oes te gaan insamel, het hulle dus ook 'n verdere taak - hulle moet bid dat God nóg werkers sou voorsien (Maier 1992:25). Die dissipels se gebed vir meer werkers om te help met die insameling van die oes word in 10:6 implisiet verhoor deurdat die gashere, wat hulle boodskap gunstig ontvang het, ook in hulle sending opgeneem word (kyk onder die hofie 'Die sending van die twee en sewentig as deelname aan die Missio Dei').

Dit is opvallend dat gebed in Handelinge 'n deurslaggewende rol speel tydens kritieke momente in die uitdra van die Evangelie vanaf Jerusalem $(1: 14,24)$ na Samaria $(8: 14-15)$ en na die uithoeke van die aarde (10:4, 9, 30-31, 11:5) (Matson 1996:151). Gebed is daarom 'n integrale deel van die kerk se deelname aan die Missio Dei.

\section{Die identiteit van die groot oes}

Die groot oes wat ingesamel moes word, kan in die konteks van Lukas-Handelinge na die Jode, die Samaritane of selfs al die nasies verwys.

Die veronderstelde Palestynse konteks van 10:1 (Jesus sou op pad na Jerusalem geen stede buite Palestina besoek nie), tesame met die feit dat die twaalf dissipels eers in 24:47 na al die nasies uitgestuur word, skep die moontlikheid van 'n eksklusiewe Joodse sending vir die twee en sewentig dissipels (Völkel 1990:369). Hier is dit belangrik om in ag te neem dat Jesus, anders as ander Joodse herstelbewegings soos die Fariseërs, nie net op 'n gedeelte van Israel gefokus het nie. Hy het eerder op die ganse Israel gefokus (Bosch 1991:26), soos bevestig deur die aanwys van twaalf dissipels, wat simbolies op die herstelde stamme van Israel dui (Johnson 1991:170).

Teenoor die siening van 'n uitgebreide maar steeds eksklusiewe Joodse gerigtheid staan Jesus se sending van boodskappers na die Samaritane in 9:51-53. Die Samaritane is 'n besondere fokus van Lukas. Net Lukas meld twee insidente tydens Jesus se reis na Jerusalem waarin Samaritane positief uitgebeeld word (10:25-37; 17:11-19). Indien verder in ag geneem word dat Jesus sy boodskappers eksplisiet verbied het om die Samaritaanse dorpe te vervloek (9:54-56), is die insluiting van die Samaritane in die dissipels se sending nie vergesog nie.

Die dissipels se sending kan egter nóg ruimer verstaan word deurdat die Lukas-evangelie verskeie rigtingwysers bevat (3:4-6; 4:22-30; 7:1-10; 13:23-30; 14:16-24; 17:11-19; 20:15-16; 24:47) wat daarop dui dat Jesus sy sending nie net tot die Joodse volk beperk het nie (Bock 2004:362). ${ }^{11}$ Só kan die getal van die gestuurdes daarop dui dat hulle 'n universele sending gehad het, aangesien daar volgens die LXX vertaling van Genesis 10 twee en sewentig nasies in die wêreld was (Marshall 1978:414415; Matson 1996:34). ${ }^{12}$ Soos die twaalf simbolies op 'n sending na al die stamme van Israel kan dui, kan die twee en sewentig op hulle beurt weer simbolies daarop dui dat die dissipels in 10:1-16 na alle nasies moes gaan (contra Bock 1996:994, 10151016)..$^{13}$

(Footnote 10 cont...)

10:6 hier, anders as in 10:1, op God self (contra Matson 1996:50; met Marshall 1978:416; Du Plessis 1995:350).

11.Dunn (2003:537-539) wys daarop dat, alhoewel Jesus nie heidene aktief opgesoek het nie, Hy altyd positief op hulle geloof gereageer het as hulle oor sy pad gekom het en dat Hy daarvoor ruimte gelaat het dat hulle in die koninkryk van God opgeneem sou word.

12.Dit sou verklaar waarom daar tekskrities onduidelikheid oor die getal van die gestuurdes in 10:1 bestaan deurdat die Masoretiese teks van Gen 10 ' $\mathrm{n}$ lys van sewentig nasies het, teenoor die LXX s'n van 72 (Matson 1996:34-35). Die

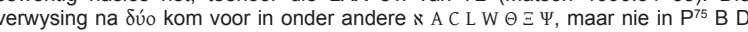
0181 nie. Dit is byna onmoontlik om tussen die twee teksvariante te kies, alhoewel die weglating van $\delta$ ó makliker is om te verklaar as die insluiting daarvan (Fitzmyer 1985:845; Nolland 1993:546).

13.Völkel (1990:369) waarsku egter teen die oorlading van die betekenis van

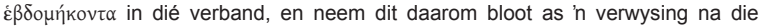
grootste heilige getal wat algemeen gebruik is $(7 \mathrm{mal} 10)$. Die vraag of Jesus 10:1-16' ' unives 10:1-16 h universele sending in gedagte gehad het, kan daarom nie net (1994:54) wys in de veband daarop dat, ahrow 1994:54) wys in dié verband daarop dat, alhoewel die uitgestuurdes 72 is, hulle twee-twee na net 36 dorpe gestuur word, in plaas van 72 soos verwag 
Deur die identiteit van diegene na wie die dissipels moes gaan, vaag te laat, benut Lukas die gedeelte as 'n begronding vir die uitbreiding van die kerk se sending na alle nasies, soos vertel in Handelinge (contra Evans 1990:445; Green 1997:411; Stein 1992:303-304). Daarom meld Lukas nie die spesifieke stede waarheen hulle gegaan het nie (Fitzmyer 1985:842). Hy laat ook die verbod teen die gaan na die heidene en die Samaritane weg, wat Jesus in die parallelle gedeelte in Mattheus 10:5 uitgespreek het (Stein 1992:307). ${ }^{14}$

In Lukas 24:46-49 word dié onduidelikheid oor wie almal deel is van die kerk se sending klinkklaar ten gunste van in universele sending opgeklaar (Goheen 2005:244). Handelinge 10:36 bevestig dié universele sending deur die bekendmaking dat, alhoewel die Here die evangelie van vrede aan Israel gestuur het, Jesus terselfdertyd ook die Here van almal is.

\section{Die dringendheid van die sending}

Die dringendheid van die dissipels se sending word telkens deur Jesus beklemtoon (Maier 1992:26). Só mag hulle nie deelgeneem het aan die tydrowende uitruil van soene, omhelsings en persoonlike nuus wat die groet van diegene langs die pad, volgens die gebruike van die eerste-eeuse Mediterreense wêreld, sou meebring nie (Dunn 2003:505; Klein 2006:377). Hulle moes ook nie tyd verkwis deur van huis tot huis te gaan nie, maar hulle moes eerder die eerste huis wat hulle vredesgroet aanvaar het as basis vir hulle sending gebruik (Klein 2006:378; Matson 1996:41) ${ }^{15}$ Om van huis tot huis te gaan om die beste behuising of kos uit te soek, sou nie net hulle gashere beledig nie, maar ook die eskatologiese dringendheid van hulle sending misken. Die koninkryk van God het immers reeds naby gekom (10:9, 11) en die oes kan dus verlore gaan as dit nie betyds van die landerye afgehaal word nie (Green 1997:359-360, 413; Nolland 1993:551-553).

\section{Die gevolge van 'n positiewe ontvangs (10:5-9) Inklusiewe tafelgemeenskap}

Moessner (1989:137-139) en Matson (1996:47-48) voer aan dat die primêre doel van die dissipels se sending was om 'n nuwe, inklusiewe gemeenskap tot stand te bring. ${ }^{16}$ Hulle doel was nie om alle mense (vandaar die verbod om mense langs te pad te groet in 10:4), óf soveel huisgesinne as moontlik, te besoek ten einde hulle te bekeer nie. Hulle doel was eerder om saam met die eerste huisgesin wat hulle verwelkom, tafelgemeenskap te beoefen. Só word die dissipels eers beveel om in dié huis wat hulle ontvang het, te bly ${ }^{17}$ en dan word hulle eksplisiet verbied om van huis tot huis te beweeg (10:7)

Die bevel om saam met die huisgesinne wat hulle ontvang, te eet, word in 10:8 herhaal. Die tafelgemeenskap waarop hulle sending afstuur, is vir Lukas sowel die loon op die werkers se arbeid (10:7c) as 'n teken van God se koninkryk wat op die huis gekom het $(10: 6,9)$. Wie met die dissipels tafelgemeenskap geniet, beoefen dit ten diepste ook met Jesus en Sy Vader wat Hom gestuur het (10:16) (vgl. Klein 2006:379; Maier 1992:27).

(Footnote 13 cont...)

indien laasgenoemde getal op die heidensending moes dui. Die sending van 36 spanne na ten minste soveel dorpe en stede getuig egter opsigself steeds van ' $\mathrm{n}$ uitgebreide sending.

14.Dié weglatings kan ook verklaar word deurdat dit bloot nie in Lukas se bronne voorgekom het nie Só kom die verbod van Mattheus 10:5 nie in Markus of die voorgekom het nie. So kom die verbod van Mattheus 10:5 nie in Markus of die
rekonstruksie van die hipotetiese $Q$-bron van Robinson en andere (2000:158) voor rekonstruksie van die kipoter ook wees dat dit nie in die gerekonstrueerde Q-bron opgeneem is nie omdat Lukas dit weggelaat het.

15.Die opdrag om niemand langs die pad te groet nie eggo ook die sending van Gehasi deur Elisa in 2 Kon 4:29 (Nolland 1993:552).

16.Kyk Denaux (1999:255-278) vir die belangrikheid van gasvryheid as teologiese motief in Lukas-Handelinge.

17.Die voornaamwoord $\alpha$ v̉ós in 10:7a beklemtoon die gedagte dat die dissipels in die huis wat hulle boodskap gunstig ontvang het, moes bly (Matson 1996:47).
Lukas beklemtoon dat die uitnodiging tot tafelgemeenskap 'n ope uitnodiging was. Die dissipels kon enige huis betree en by elke ete aansit (Matson 1996:43-44; Neyrey 1991b:381). Anders as vir die Jode was geen huis of ete meer vir hulle onrein nie. Die Jode het naamlik geweier om saam met heidene in hulle huise te eet (Hand 10:28; 11:3, 12) (Esler 1987:76-86). Dit is daarom nie vreemd dat die Joodse gelowiges in Jerusalem se klag teen Petrus nie was dat hy die Evangelie aan onbesnedes verkondig het nie, maar eerder dat hy saam met hulle geëet het (Hand 11:3)

Jode het wel soms by uitsondering saam met nie-Jode geëet, maar dan het hulle spesifiek hulle eie kos gebring wat hulle dan apart geëet het (Esler 1987:80-84). Dit is opvallend dat die dissipels in 10:4 geen kos (soos gesuggereer deur die verbod op die neem van'n drasak) of geld om hulle eie kos mee te kon koop, kon saamneem nie (Moessner 1989:135; Schürmann 1994:73). Die Fariseërs was volgens die Misjna nóg strenger oor saam met wie hulle bereid was om te eet. Hulle het selfs van hulle mede-Jode verwag om 'n kleed aan te trek wat ritueel gereinig was en deur die gasheer verskaf is (m.Demai 2:2-3). Al het die Samaritane op hulle beurt sekere van die Jode se gebruike rondom etes gedeel (Stein 1992:305), is hulle egter deur die Jode as uitgeworpenes beskou, met die gevolg dat tafelgemeenskap met hulle ook afgewys is (Johnson 1991:170).

Jesus se herhaalde opdrag om alle kos te eet, het die grens tussen rein en onrein afgebreek (Matson 1996:39, 43-44; Neyrey 1991a:381). Etes is sodoende vir die kerk verander van seremonies wat mense uitsluit na dié wat hulle insluit in God se koninkryk (vgl. Malina \& Rohrbaugh 1992:367-368). In navolging van Jesus, wat verskeie sosiale en religieuse gebruike verontagsaam het deur saam met almal te eet $(5: 27-33 ; 7: 34,36-50 ; 14: 1-$ 24; 19:1-10) (Achtemeier et al. 2001:167), moes die dissipels daarom in weerwil van die Joodse reinheidswette met almal tafelgemeenskap beoefen (contra Bock 1996:999; Klein 2006:378; Morris 1988:200)..$^{18}$ Sodoende sou hulle illustreer dat selfs die armes en die oneervolles (vgl. 14:12-13) welkom was in God se koninkryk (Denaux 1999:258-260). Lukas stel dit dan ook eksplisiet in 13:29 dat alle nasies welkom was aan die tafel van God (Malina \& Rohrbaugh 1992:368).

Die Evangelie volgens Lukas as geheel bied dus 'n uitgebreide begronding vir die vroeë kerk se inklusiewe tafelgemeenskap, soos beoefen deur Petrus in Handelinge 10:25-36 en 11:3.

\section{Die genesing van siekes en die verkondiging van die koninkryk van God}

In Jesus se tweede uitspraak rakende 'n positiewe ontvangs (10:8-9), word die dissipels beveel om nie net die gasvryheid van hulle gashere te geniet nie, maar ook om die siekes daar teenwoordig te genees en die nabyheid van die koninkryk aan hulle te verkondig. Genesing dien in 10:8-9 as 'n sinekdogee vir die volle herstel wat God se koninkryk meebring (Green 1997:414-415). As sigbaarmaking van God se naderende koninkryk was genesings 'n belangrike deel van Jesus se reis na Jerusalem, soos blyk uit die drie genesings wat Hy daartydens verrig het (13:10-17; 14:1-6; 17:11-19).

\section{Die reaksie van die dissipels op weerstand teen hulle sending (10:10-11)}

Jesus beklemtoon deur die herhaling van sowel $\dot{\alpha} \theta \in \tau \hat{\omega} v$ as $\dot{\alpha} \theta \epsilon \tau € \hat{\imath}$ in vers 16 dat die dissipels, soos Hy reeds in 9:51-56 ervaar het, weerstand sou ervaar (Bock 1996:1005; Du Plessis 1995:349). Dit gebeur dan ook toenemend in Lukas soos wat hulle saam met Jesus na Jerusalem gereis het (Achtemeier et

18.Volgens Lukas het Jesus Hom nie daaraan gesteur of iemand sy hande was of nie $(11: 38)$, wie wat eet, waar $(6: 4)$ of met wie nie (15:2). Die gebruiklike Joodse etiket rakende etes $(7: 39 ; 14: 7-14 ; 17: 7-8)$ was vir Jesus sonder enige waarde gewees (Malina \& Rohrbaugh 1992:368) 
al. 2001:166-167). Die dissipels sou dus in Jesus se lyding en verwerping deel, net soos Hy weer op sy beurt in hulle s'n sou deel (vgl. 10:16). Dit is egter opvallend dat daar in Handelinge, anders as in Lukas, geen voorbeeld is van 'n huishouding wat nie die dissipels en hulle boodskap ontvang het nie (Matson 1996:33, 46-47, 194-196).

\section{Die weerloosstelling van die dissipels}

Die dissipels se reaksieop die verwagte vyandige gesind heid van sommige stede moes nie wees om elke moontlike voorsorgmaatreël te tref nie. Hulle moes eerder hulleself, in gehoorsaamheid aan Jesus, nóg weerloser maak deur doelbewus geen voorsorg te tref nie (Liefeld 1984:937; Nolland 1993:559). Hulle moes hulle losmaak van alle impedimenta deurdat hulle geen beurs

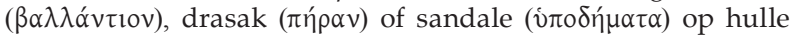
sending moes saamneem nie (10:4) (Matson 1996:38). Hulle was sodoende totaal afhanklik van God se sorg vir hulle deur ander (Luk 10:7b) (Denaux 1999:262; Marshall 1978:414, 418). ${ }^{19}$

Die moontlikheid bestaan dat dié opdragte aan die dissipels hulle ook moes onderskei van rondreisende Sinici ${ }^{20}$ deurdat hulle, anders as laasgenoemde, nie 'n staf ${ }^{21}$ of 'n drasak ( $\left.\pi \eta ́ p \alpha v\right)$ mag gedra het nie. Die Sinici het ook volgens Josefus soms kaalvoet gereis (Bell. Jud. 2:126), wat die vraag laat ontstaan of die dissipels ook kaalvoet moes reis en of hulle bloot nie ' $n$ ekstra paar sandale mag saam geneem het nie. Die voorskrifte in dié verband in die sinoptiese evangelies is nie eenvormig nie. In Mark 6:9 mag die twaalf dissipels wel sandale dra, maar nie in Matt 10:10 nie. Indien hulle wel kaalvoet moes reis (Bock 1996:997; contra Morris 1988:199; Nolland 1993:551), sou dit dien as 'n teken van hulle totale weerloosheid as lammers tussen wolwe (10:3) en hulle identifikasie met die armes (Schürmann 1994:64).

\section{Simboliese protes deur die dissipels}

As hulle boodskap van vrede verwerp sou word, moes die dissipels hulle simbolies van dié stede distansieer deur dié stede se stof van hulle voete af te skud in die hoofstrate ( $\tau \dot{\alpha} \varsigma$ $\pi \lambda \alpha \tau \varepsilon i ́ \alpha \varsigma$ ) (Bock 1996:1001; Evans 1990:450). Dié gebruik kan waarskynlik teruggevoer word na die Joodse gewoonte om ná 'n besoek aan heidense lande die stof van hulle reis van hulle voete af te skud. Dit was enersyds om te keer dat die stof die Heilige Land sou kontamineer en om andersyds te wys dat hulle niks met die heidense lande te doen wou hê nie (Malina \& Rohrbaugh 1992:346; contra Nolland 1989:428). Die dissipels moet dus nie-ontvanklike stede soos heidense gebiede behandel (Schürmann 1994:75). Naas die simboliese protes moes die dissipels ook teenoor die stede verklaar dat die koninkryk van

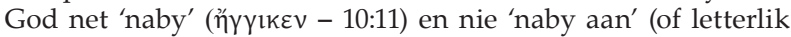

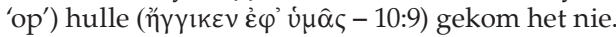

Die koninkryk van God bring dus skeiding nie weens menslike vooroordele nie (soos om vooraf te besluit aan wie God se vrede aangebied sal word), maar na aanleiding van elke huishouding se reaksie op die koms daarvan (Green 1997:414). 'n Negatiewe

19.In 22:31-38, wanneer Jesus se bediening op sy kruisiging in Jerusalem afstuur, en die Satan Petrus direk bedreig, wysig Jesus sy opdragte aan die verskillende dissipels soos (is

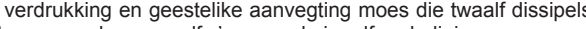
saamneem Stein 1992:554; Nolland 2002.1072). Die feit dat Handelinge geen melding maak van die dra van swaarde, ' $n$ beurs of reissak deur die apostels nie, wil dit ook laat blyk dat Jesus in Lukas 22 slegs ' $n$ tussentydse reëling tref (Tannehill 1986:267; contra Schürmann 1994:65).

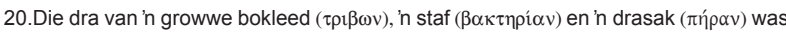
volgens Epiktetus kenmerkend van rondreisende Sinici (Diss. 3.22.10, 50). Die rondreisende Esseners het ook volgens Josefus sonder ekstra klere en skoene gereis. Hulle het ook geen voorsiening gemaak vir die saamneem of aankoop van kos nie, maar was volgens Josefus vir hulle versorging van mede-Esseners afhanklik (Bell. Jud. 2.124-7). Jesus se dissipels sou egter meer weerloos as dien die ander nie, maar na diegene wat nog nie mededissipels was nie (Moessner 1989:136).

21.Só in Mattheus 10:10 en Lukas 9:3. In Markus 6:8 word die dissipels egter wel deur Jesus toegelaat om ' $\mathrm{n}$ staf saam te neem.

\begin{tabular}{|c|c|}
\hline Lukas 10:1-16 & Lukas $19: 1-10$ \\
\hline $\begin{array}{l}\text { Jesus word die Here (ó кúpış) genoem } \\
(10: 1)\end{array}$ & $\begin{array}{l}\text { Jesus word die Here (ròv kúplov) genoem } \\
(19: 8)\end{array}$ \\
\hline $\begin{array}{l}\text { Boodskappers moet in die stede ingaan } \\
(10: 1,8 \text { en } 10)\end{array}$ & $\begin{array}{l}\text { Jesus gaan in die stad van Jerigo in } \\
(19: 1)\end{array}$ \\
\hline 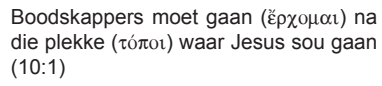 & 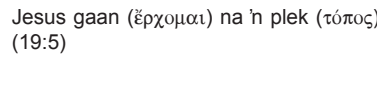 \\
\hline $\begin{array}{l}\text { Jesus is op die punt }(\eta \mu \mu \lambda \lambda \in v) \text { om te } \\
\text { kom }(10: 1)\end{array}$ & $\begin{array}{l}\text { Jesus was op die punt (ñ } \mu \in \lambda \lambda \in v) \text { om } \\
\text { verby te gaan (19:4) }\end{array}$ \\
\hline 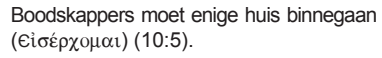 & 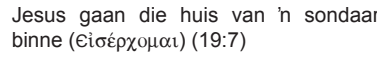 \\
\hline $\begin{array}{l}\text { Die boodskappers moet vrede aan die } \\
\text { huis (oî́к૬) verkondig (10:5) }\end{array}$ & $\begin{array}{l}\text { Jesus bring verlossing vir die huis } \\
\text { (oî́रos) (19:9) }\end{array}$ \\
\hline $\begin{array}{l}\text { Die seun van vrede ontvang die } \\
\text { boodskappers gasvry }(10: 6)\end{array}$ & $\begin{array}{l}\text { Die seun van Abraham ontvang Jesus } \\
\text { gasvry (19:9b) }\end{array}$ \\
\hline $\begin{array}{l}\text { Die boodskappers bly aan }(\gamma \mu \varepsilon ́ v \omega) \text { in die } \\
\text { huis }(10: 6)\end{array}$ & $\begin{array}{l}\text { Jesus bly }(\mu \varepsilon ́ v \omega) \text { in die huis van } \\
\text { Saggeus (19:5) }\end{array}$ \\
\hline
\end{tabular}

respons deur die hoof van die huis sou lei tot die terugkeer van die vrede, wat in effek die oorspronklike vredesgroet in 'n oordeel oor hulle sou omskep (Marshall 1978:420). Die tema van oordeel is dus nie afwesig in 10:1-16 nie deurdat diegene wat nie die vrede van God aanneem nie deur Hom geoordeel sal word (10:11-15). Jesus rig om dié rede 'n ernstige waarskuwing (10:12) aan alle ongasvrye stede na aanleiding van die voorbeeld van Sodom (vgl. Gen 19), wie se lot spreekwoordelik geword het as gevolg van die inwoners se gebrek aan gasvryheid teenoor God se boodskappers (Green 1997:416; Johnson 1991:168). Ongasvrye stede moes daarvan kennis neem dat hulle straf selfs erger sou wees as Sodom s'n op die oordeelsdag ( $\tau \hat{\eta} \dot{\eta} \mu \varepsilon \dot{\varepsilon} \rho \underline{\varepsilon} \kappa \epsilon \in \dot{i} v \grave{i})$ (Nolland 1993:555).

Jesus rig ook by name 'n reeks apostrowe aan Gorasin, Betsaida (10:13) en Kapernaum (10:15) om hulle te vermaan. Laasgenoemde, waar Jesus 'n groot deel van Sy bediening verrig het $(4: 23 ; 7: 1)$, ontvang 'n waarskuwing dat dit nie verhoog sou word soos wat dit verwag het nie, maar eerder in die doderyk ( $\alpha \hat{q} \delta \eta \varsigma)^{22}$ gewerp sou word. ${ }^{23}$ Onderliggend aan Jesus se oordeelsuitspraak is die gedagte dat die koninkryk

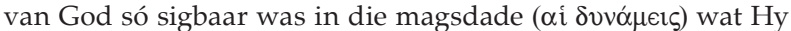
in hierdie drie Joodse dorpe verrig het (vgl. 4:41-44; 7:1-10) dat heidense stede hulle sou bekeer het indien hulle dit aanskou het (Nolland 1993:556).

\section{DIE VOORBEELD VAN JESUS}

Lukas verbind die sending van die twee en sewentig direk aan Jesus s'n deur te verklaar dat hulle vooruit moes gaan na die stede en dorpe wat Hy van plan was om te besoek (10:1b). Soos wat Jesus huishoudings besoek het ten einde siekes te genees (4:38-41; 7:1-10; 8:41-42, 49-56), en saam met almal geëet het (5:29-32; 7:36-50; 11:37-54; 14:1-24), moes die twee en sewentig dit ook doen (10:8-9).

Op reis na Jerusalem betree Jesus dan ook verskeie dorpe en huise $(10: 38 ; 11: 37 ; 14: 1)$ en aan die einde van die reis vertel Lukas van die bekering van Saggeus en sy familie deur Jesus (19:1-10). Laasgenoemde is die enigste sodanige voorbeeld in die Lukas-evangelie. Uit die intertekstuele verband tussen 19:110 en 10:1-16 (sien die onderstaande tabel) is dit duidelik dat Jesus volgens Lukas nie net aan die dissipels die opdrag gegee het om na verskillende dorpe en stede te gaan nie, maar ook aan hulle die voorbeeld gestel het deur dit self te doen (Matson 1996:75, 83).

22.Hades (שאול) is die teenpool van die hemel (Ps 139:8; Am 9:2) (Marshall 1978:425; Stein 1992:306). Vir die Grieke was dit die sfeer waarin die dooies soos skaduwees vreugdeloos voortgeleef het. In die Nuwe Testament dui dit op die woonplek van die veroordeelde onregverdiges (16:23; Op 20:13-14) (Bock 1996:1004-1005).

23. Die verwysing hier is waarskynlik' $\mathrm{n}$ eggo van die koning van Babilon se verwaande uitspraak dat hy na die hemel sou opvaar, maar wie se lot die onderwêreld was (Jes 14:13-14) (Nolland 1993:557). 


\section{DIE VOORTSETTING VAN DIE SENDING VAN DIE TWEE EN SEWENTIG IN HANDELINGE}

Lukas 10:1-16 begrond nie net die kerk se sending na die wêreld teologies in die sending van Jesus nie. Dit verskaf ook 'n modus operandi vir die kerk in Handelinge se voortsetting van die twee en sewentig se sending (Matson 1996:27, 35-38; Tannehill 1986:235). ${ }^{24}$ Só word die sending van die twee en sewentig na

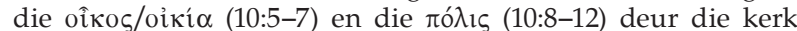
van Handelinge volgens Lukas verder gevoer deurdat daar telkens na verskillende stede uitgereik is (Hand 8:5, 8, 40; 13:14, 44,$48 ; 14: 1,4,20-21 ; 15: 36 ; 16: 4,12 ; 17: 1,5-8 ; 18: 10$ en 19:26, 29). Die dissipels en apostels in Handelinge het ook meestal tweetwee gereis soos in Lukas 10:1 deur Jesus beveel is. ${ }^{25}$ Paulus en Barnabas sou selfs in Antiogië in Pisidië (Hand 13:51) en in die sinagoge van Korinte (Hand 18:6) die opdrag om die stof van hulle voete af te vee (Luk 10:10-11), uitvoer.

In Handelinge word ook spesifiek van die bekerings van die oỉíi $\alpha$ van Cornelius (10:1-11:8), Lydia (16:14-15), die Romeinse tronkbewaarder (16:22-34) en Krispus (18:8) vertel. Elkeen van die vertellings is uiters belangrik deurdat hulle aandui hoedat die kerk verskeie grense oorgesteek het in die uitdra van die Evangelie. Só is Cornelius en Lydia onderskeidelik die eerste nie-Joodse man en vrou wat saam met hulle verskillende huishoudings tot bekering gekom het. Die Romeinse tronkbewaarder en sy huis is op hulle beurt die eerste volwaardige heidene wat tot bekering kom (Cornelius en Lydia was reeds godvresendes toe hulle Christene geword het - Hand 10:1; 16:14). Krispus is weer die eerste hoof van 'n sinagoge wat saam met sy huis tot geloof gekom het. Sy bekering bevestig, saam met die ander s'n, dat huise, en nie die tempel of sinagoge nie, in Handelinge dié ruimte geword het waar die Evangelie deur mense ontvang is (vgl. Hand 20:20). Só het die kerk dan ook volgens Lukas van huis tot huis gegroei (Elliot 1991:211-240; Matson 1996:41, 48-49, 131, 187).

\section{SLOT}

Lukas 10:1-16 maak dit duidelik dat die kerk aktief moet deelneem aan die Missio Dei, soos bekendgemaak in die $\mathrm{Ou}$ Testament en voortgesit in Lukas-Handelinge. Deur verskeie stilistiese en tematiese ooreenkomste koppel Lukas die sending van die twee en sewentig aan sowel Jesus s'n in die Lukasevangelie (4) as aan die kerk s'n in Handelinge (5). As sulks dien die gedeelte as 'n bloudruk, voorskou en begronding vir die kerk se sending buite die grense van die Joodse land en volk (3), soos beveel in 24:46-49 en voortgesit in Handelinge.

Terwyl Lukas, in afwagting van die kerk se sending na die heidene in Handelinge, beide die identiteit van die gestuurdes en hulle potensiële gashere nie stipuleer nie, bestaan daar by hom geen onsekerheid oor die dringendheid en die gevaar verbonde aan hulle sending nie.

Die uitstuur van die twee en sewentig dissipels deur Jesus het die daarstelling van 'n nuwe inklusiewe gemeenskap en die genesing van alle siekes, as sigbare gestaltes van God se komende koninkryk, ten doel gehad. As gestuurdes van God moes die dissipels hulle deur geen sosiale, religieuse of ekonomiese grense laat stuit nie. Die dissipels moes enige huis betree en by elke ete aansit.

24. Tematiese en linguistiese merkers in Lukas 10:1-16 wat dit spesifiek aan die kerk se voortgaande sending na die wêreld in Handelinge koppel, is (a) die werkwoord

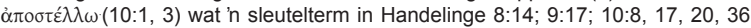

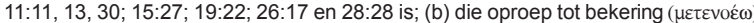
in $10: 13$ wat nie net in Lukas $11: 32 \cdot 13: 3,5 ; 15: 7,10 ; 16: 30$ voorkom nie, maar ook in Handelinge 2:38; $5: 31$ en 26:20 en (c) die aanvaarding ( $\delta$ źxo $\left.\alpha_{1}-10: 8,10\right)$ van die dissipels, wat ook weer in Handelinge $2: 41 ; 8: 14 ; 11: 1 ; 15: 4 ; 17: 7,11 ; 18: 27 ; 21: 17$; 22:18 en 28:7 ter sprake kom (Matson 1996:35-38).

25.Voorbeelde hiervan in Handelinge is Petrus en Johannes (8:14), Barnabas en Saulus (13:2), Judas en Silas (15:22, 32-33) en Paulus en Silas (15:40).
Die sending van die dissipels sou egter wel skeiding bring tussen mense wat God se vrede ontvang en dié wat dit verwerp. Hulle moes weerstand teen hulle sending te wagte wees en hulleself daarop voorberei, enersyds deur hulleself weerloos te stel en andersyds deur God se oordeel te verkondig aan almal wat hulle boodskap verwerp het. Diegene wat die dissipels en hulle boodskap egter gunstig ontvang het, sou saam met hulle huisgesinne in die Missio Dei van die kerk opgeneem word.

Lukas 10:1-16 is 'n sleutelteks vir die verstaan van die kerk se sending volgens Lukas. Dit herinner die kerk van alle tye daaraan dat die kerk as deelnemer aan die Missio Dei oor alle grense heen uitgestuur word om die koms van God se koninkryk deur woord en daad te verkondig.

\section{LITERATUURVERWYSINGS}

Achtemeier, P.J., Green, J.B. \& Thompson, M.M., 2001, Introducing the New Testament - Its literature and theology, Eerdmans, Grand Rapids.

Betz, H.D., 1996, 'Apostle', in D.N. Freedman (ed.), The Anchor Bible Dictionary, vol. 1, pp. 309-311, Doubleday, New York.

Bock, D.L., 1996, Luke 9:51-24:53 (Baker Exegetical Commentary on the New Testament), Baker Academic, Grand Rapids.

Bock, D.L., 2004, 'Luke', in S. McKnight \& G.R. Osborne (eds.), The face of New Testament studies - A survey of recent research, bl. 349-372, Baker Academic, Grand Rapids.

Bosch, D., 1991, Transforming mission - Paradigm shifts in the theology of mission, Orbis, Maryknoll.

Crossan, J.D., 1992, The historical Jesus - The life of a Mediterranean Jewish peasant, Harper, San Francisco.

Denaux, A., 1999, 'The theme of divine visits and human (in) hospitality in Luke-Acts - Its Old Testament and GraecoRoman antecedents', in J. Verhyden (ed.), The unity of LukeActs, pp. 255-280, Peeters, Leuven.

Dunn, J.D.G., 2003, Jesus remembered, Eerdmans, Grand Rapids. (Christianity in the Making 1).

Du Plessis, I.J., 1995, Die Evangelie volgens Lukas [The Gospel according to Luke], deel 1, Lux Verbi, Kaapstad.

Elliot, J.H., 1991, 'Temple versus household in Luke-Acts: The contrast in social institutions', in J.H. Neyrey (ed.), The social world of Luke-Acts - Models for interpretation, pp. 211-240, Henderson, Peabody.

Evans, C.F., 1990, Saint Luke (Trinity Press International New Testament Commentary), SCM Press, Londen.

Evans, C.F., 2002, Luke 1:1-9:20 (Word Biblical Commentary 35A), Word Incorporated, Dallas.

Esler, P.F., 1987, Community and gospel in Luke-Acts, Journal for the Study of the New Testament, suppl. ser. 57.

Fitzmyer, J.A., 1985, Luke X-XXIV (The Anchor Bible), Doubleday, Garden City.

Goheen, M., 2005, 'A critical examination of David Bosch's missional reading of Luke', in C.G. Bartholomew, J.B. Green \& A.C. Thiselton (eds.), Reading Luke (Scripture and Hermeneutics Series 6), pp. 229-264, Zondervan, Grand Rapids

Green, J.L., 1997, The Gospel of Luke (The New International Commentary on the New Testament), Eerdmans, Grand Rapids.

Johnson, L.T., 1991, The Gospel of Luke (Sacra Pagina Series 3), Liturgical Press, Collegeville.

Johnson, L.T., 1999, The writings of the New Testament: An interpretation, 2nd edn., Fortress Press, Philadelphia.

Keifert, P., 2006, We are here now. A new missional era, Allelon, Eagle.

Klassen, W., 1996, 'Peace', in D.N. Freedman (ed.), The Anchor Bible Dictionary, vol. 5, pp. 206-208, Doubleday, New York.

Klein, H., 2006, Das Lukasevangelium [The Gospel according to Luke], (Kritisch-exegetischer Kommentar uber das Neue Testament), Vandenhoeck \& Ruprecht, Göttingen.

Liefeld, W.L., 1984, Luke (The Expositor's Bible Commentary), Zondervan, Grand Rapids. 
Litwak, K.D., 2005, Echoes of scripture in Luke-Acts: Telling the history of God's people intertextually, Journal for the Study of the New Testament, suppl. ser. 282.

Louw, J.P. \& Nida, E.A., 1988, Greek-English lexicon of the New Testament based on semantic domains, vol. 2, UBS, New York.

Maier, G., 1992, Lukas-Evangelium [The Gospel according to Luke], part 2, (Edition-C-Bibelkommentar), Hanssler, NeuhausenStuttgart.

Malina, B.J. \& Rohrbaugh, R.L., 1992, Social-science commentary on the synoptic Gospels, Fortress Press, Minneapolis.

Marshall, I.H., 1978, Commentary on Luke (New International Greek Testament Commentary), Eerdmans, Grand Rapids.

Matson, D.L., 1996, Household conversion narratives in Acts Pattern and interpretation, Journal for the Study of the New Testament, suppl. ser. 123.

Moessner, D.P., 1989, The lord of the banquet - The literary and theological significance of the Lucan travel narrative, Fortress Press, Minneapolis.

Morris, L., 1986, New Testament Theology, Academie Books, Grand Rapids.

Morris, L., 1988, Luke, 2nd revised edn., Inter-Varsity Press (Tyndale), Leicester.

Neyrey, J.H., 1991a, ‘The symbolic universe of Luke-Acts: “They turn the world upside down"', in J.H. Neyrey (ed.), The social world of Luke-Acts - Models for interpretation, pp. 271-304, Henderson, Peabody.

Neyrey, J.H., 1991b, 'Ceremonies in Luke-Acts: The case of meals and table-fellowship', in J.H. Neyrey (ed.), The social world of Luke-Acts-Models for interpretation, pp. 361-387, Henderson, Peabody.

Nolland, J., 1989, Luke 1-9:20 (Word Biblical Commentary 35A), Word, Dallas.

Nolland, J., 1993, Luke 9:21-18:34 (Word Biblical Commentary 35B), Word, Dallas.

Nolland, J., 2002, Luke 18:35-24:5 (Word Biblical Commentary $35 \mathrm{C})$, Word, Dallas.

Robinson, J.M., Hoffmann, P. \& Kloppenborg, J.S., 2000, The critical edition of Q: Synopsis including the Gospels of Matthew and Luke, Mark and Thomas with English, German, and French translations of $Q$ and Thomas, (Hermeneia: a Critical and Historical Commentary on the Bible), Fortress Press, Minneapolis.
Rohrbaugh, R.L., 1991, 'The pre-industrial city in Luke-Acts: Urban social relations', in J.H. Neyrey (ed.), The social world of Luke-Acts-Models for interpretation, pp. 125-149, Henderson, Peabody.

Stein, R.H., 1992, Luke (The New American Commentary 24), Broadman \& Holman, Nashville.

Schürmann, H., 1994, Das Lukasevangelium - Kommentar zu Kapitel 9,51-11 [The Gospel according to Luke], 5, (Herders theologischer Kommentar zum Neuen Testament 3), Herder, Freiburg.

Tannehill, R.C., 1986, The narrative unity of Luke-Acts - A literary interpretation, vol. 1, Fortress Press, Philadelphia.

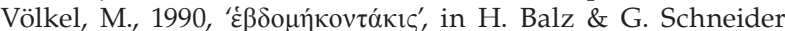
(eds.), Exegetical dictionary of the New Testament, vol. 1, pp. 369, Eerdmans, Grand Rapids.

Wright, C.J.H., 2004, 'Mission as a matrix for hermeneutics and biblical theology', in C. Bartholomew, M. Healy, K. Möller \& R. Parry (eds.), Out of Egypt - Biblical theology and biblical interpretation, pp. 102-142, (Scripture and Hermeneutics Series 5), Zondervan, Grand Rapids.

Wright, C.J.H., 2006, The mission of God. Unlocking the Bible's grand narrative, Inter-Varsity Press, Nottingham.

\section{Klassieke, Hellenistiese en Joodse geskrifte}

\section{Epiktetus}

Diss.

Dissertationes

Josefus

Bell. Jud. Bellum Judaicum

Misjna

m.Demai

Demai 